\title{
Las primas. Y sin nostalgia del absoluto.
}

\section{Nieves Olcoz}

En la complicidad que Marco Antonio de la Parra ha mantenido siempre con una ambiciosa dirección escénica, a la que el dramaturgo sabe seducir desde sus desafiantes acotaciones, Las primas toma la puerta abierta del melodrama. Tomadas como sugerencia para indicaciones productivas de más querer saber en la actuación y la ocupación del espacio, estas didascalias se ofrecen como un cuaderno de dirección y reflexión sobre la actuación desde el punto de vista de los actores. Las actrices deberán tener en cuenta en la defensa del personaje que Ismenia y Emilia están concebidas desde el histrionismo, la seducción lésbica maldita y velada, la escasa representación del amor lésbico en la cultura occidental, fuera del excedente de la pornografía para consumo masculino. Se requieren intérpretes para personajes de peso capaces de un innovador soneto del amor oscuro, una fantasía lorquiana de mujeres caballo convenientemente domesticadas por cierto juego de reescritura del melodrama. Del melodrama al estilo de Fassbinder: envolvente y envuelta, manipuladora activa y pasiva, seductora y seducida, juego de víctimas y victimarios.

El teatro empieza con la elección del género (gramático y sexuado) como acto poético. La seducción de este escenario hizo una aparición estelar, como memoria histórica de la mujer (entonces metáfora del cuerpo del dolor de la nación en el olvidado siglo XX) en Las costureras, ganadora de la Muestra Nacional de Dramaturgia en Santiago de Chile el año 2002 con un montaje que pasó por la maestría de la dirección escénica y la interpretación de Elsa Poblete y Gustavo Meza. Entonces Emilia invocaba a un personaje simple, mestizo y sin clase de una lealtad esclava a su patrona y con una relación grotesca con la sexualidad. Emilia empezó siendo en el repertorio de mujeres De la Parra una broma de la cultura popular de la risa y un homenaje a los de abajo. Ahora incorpora a una bella acuariana, detenida en la duda y 
el apego, otorgando a su prima Ismenia, con tablas de diva, un movimiento cercano a la danza, una suerte de baile, de un ir y venir del amor, el recelo, la censura, el repliegue, la culpa, la vida y la muerte, la fuga y el retorno a lo convencional.

El amor como un bailaor de soledades, arena de recámara, melodrama de director de cine alemán, crónica sentimental cosmética, cruel misterio evitado de cuanto esconde o se refugia en la ronda de la conciencia. Gravedad de la soledad sonora entre los pliegues de Ismenia que soñará siempre Antígonas. Decisión de bailar solo como pathos ridículo, un trágico de consumo para los miedos de nuestra hipocresía social. Lesbianismo: un sueño de caderas como debate político. Arranca el planteamiento. Práctica de lo real sin nostalgia del absoluto.

Personajes del melodrama: pacientes de la nada quebrados por la impotencia de no existir y el esfuerzo descomunal de satisfacer otros deseos. Pierden las intenciones, hacen proyectos de sentido en una sensualidad mórbida, una resistencia histriónica al ser desde el aparecer que nunca es contemporáneo a sí mismo. Deformación del personaje en un pensamiento débil que se exhibe paso a paso, representado en la obscenidad de la caída. Los extremos del gesto son bienvenidos en la escena, aventurados para ser sosteniblemente traicionados, en la pobre penetración del amor huido. Ismenia y Emilia se contagian de los peores hábitos para sostener la pasión y la carne: cumple el arquetipo del miedo, sabe hacer la genealogía de la tumba, de la muerte en vida, el hábito de la mentira social. Por entretenida cobardía.

Personajes que entre mirada y mirada saltan al vacío, en cada movimiento dramático abren heridas como un deporte. Se abre la teoría del juego a inagotables espacios latentes que no tienen mapa escénico, a acotaciones implícitas que generan en cada línea impulsos para la acrobacia sentimental, detenida e ilusionista, desde el escándalo de las metáforas del salto y la herida.

La herida se decora con estupor y eficacia femenina. La elección del mundo de la ropa, las telas, el diseño, intenta crear una atmósfera donde lo sensual tiña desde el texto hasta la puesta. Provoca saber hacer con las deudas del sentimiento. Retorcerse en la acción física hasta renunciar a la presencia escénica. Pavoneo de los carácteres que se llenan en la cavidad más gruesa de las palabras. Nos dejan sin imágenes el despecho de los corazones de las dos divas encerradas.

Toca hacerle el juego al melodrama. Jugar al teatro es un código deontológico para el dramaturgo. La teoría del juego es la única canalización permitida a la entropía en el taller de escritura de De la Parra y su pasión por 


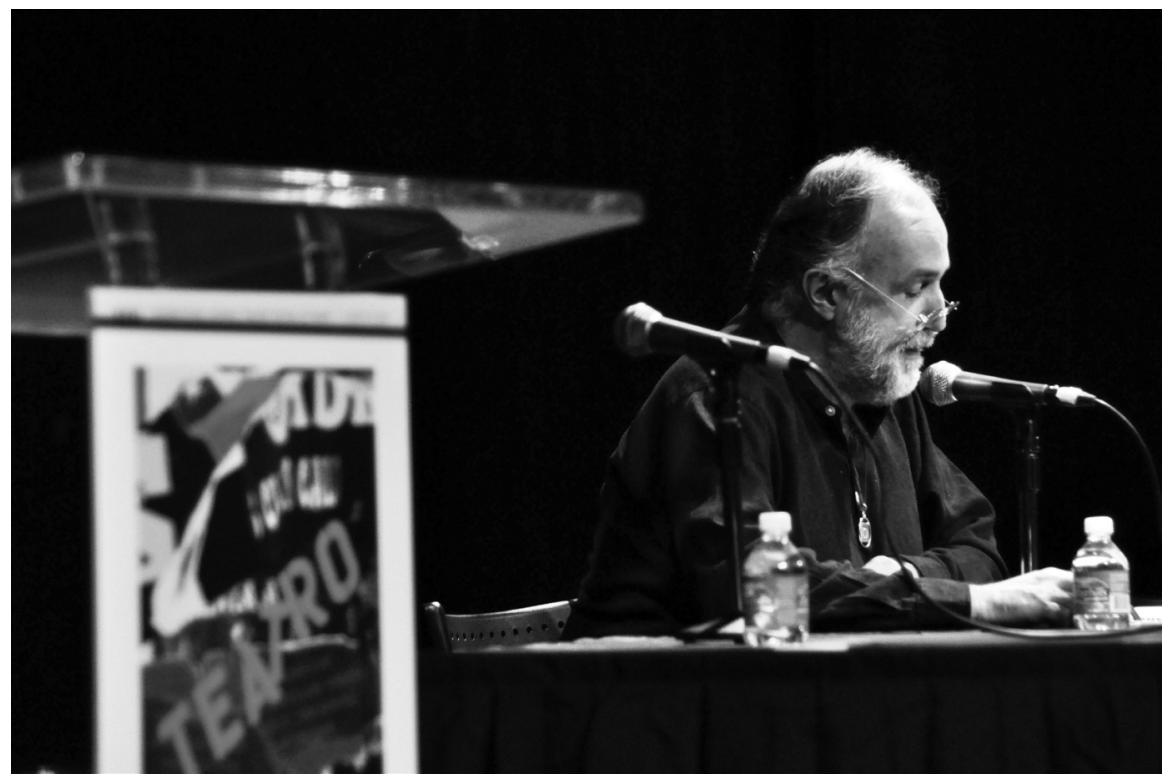

Marco Antonio de la Parra en el XXVI Festival Internacional de Teatro Hispano de Miami en julio de 2011. Foto: Sara McCranie.

la libertad creativa. Reír del dolor es necesario desde el ciclo iniciado en las comedias bárbaras de la escritura vibrante que el dramaturgo gestionó en el cambio de siglo. En el corazón negro del lesbianismo no hay más heroínas que la ley de dependencia de un deseo feroz, alimentado a escondidas y diseñado en su escaparate hasta la exacerbación. Los estímulos son baratos, los sentimientos abusivos. Una canción de Edith Piaf convenientemente afónica como sugerencia para empezar las improvisaciones del elenco y una parrafada de Cafrune como línea de pensamiento para incorporar una melancolía que atraviesa el escenario sin condición de posibilidad. Valen todas las bromas estéticas para el horror al vacío de una heroína del sentimentalismo. La e-moción, la energía en movimiento que la mujer pone en juego, cuando el corazón es un cazador solitario, termina en el más narcisista de los saltos cuerpo a cuerpo. Del divertimento del nudo, la crisis exasperante y el enredo exagerado, regresamos a la tragedia como destino en el desenlace y a la causa política de la cultura.

No hay muerte de diseño y el solo intento de estilizar el salto mortal hace del gesto melodramático una herramienta fundamentalista de la interpretación. Son extremos y peligros de la representación que cuestionan el canon del autor, pero recompensan el compromiso del dramaturgo, un esteta 
del drama como movimiento inextinguible, receptivo al dragón agotado de la economía postmoderna de la representación, pero buscando el fuego de la escena viva para fracasar en la perspectiva del otro.

Fassbinder es ofrecido como guía iniciático al museo de nuestra contraída escucha transpersonal. El autor convoca a un público lorquiano del teatro bajo la arena, sobreviviente del aburrimiento que tanto admira en su paradigma sociocultural agotadísimo. Sloterdïjk es el futuro de la filosofía pero nadie lo lee para cambiar de vida. Ha inventado a Emilia en el inconsciente colectivo y ha denunciado a Ismenia en las resilencias de la tradición cuando De la Parra se sienta a hacer trabajo de mesa. Pudimos ser Brecht, pero nos daba vértigo, pudimos ser Beckett, se plantea el dramaturgo en oficio de pérdida, pero hoy apenas sabemos hacer televisión. El deseo y la totalización tientan su escritura dramática en una era basura en capital simbólico que ha banalizado el surrealismo y agota al subconsciente con antidepresivos.

Las primas es pieza admirable que reconoce el coraje del traidor y del cobarde, la heroína como droga del telar conjuntivo del corazón condenado al naturalismo. Expresar no quiere decir significar y esta trampa del cuerpo político que agota nuestra existencia, encuentra en el diálogo melodramático de estas dos mujeres el compromiso orgánico complejo de hacer escena. Tanteo pasmoso de las poéticas más que conocidas, como dirección artística irrefutable. Texto probado para el laboratorio del cuerpo sensible. Su actor de repertorio es un artista como saltimbanqui de atractiva peligrosidad emotiva. El habla escénica es elaborada como una prueba de tensión circense con herramientas básicas para interpretar el secreto y la obscenidad entre las propuestas de la única acción física que no se va a realizar: hacer el amor.

La vida privada y la intimidad violada son escenarios de habitación compartida a puerta cerrada: Tanatos que ahoga a Eros. Fantasía para una caja escénica entrecosturas del cuerpo y el alma de la que el público extrae constantes transferencias transpersonales sobre su entidad psicoanalítica. La partitura de la actriz suena a tacones lejanos y es código precioso de rituales cotidianos desamortizados y desobedientes como proyecto de sentido. La estilística es semántica que revela cada aprendizaje de lo oculto, el peligro morboso de abastecer el ser con la negación y la mentira. La autodestrucción está soñada y pronunciada en cada destello de la productividad escénica. El juego de la ocultación y su exhibicionismo sinuoso y barroco es catártico por la profundidad significativa de su risa, intensa, triste y pecaminosa. Hay una ironía trágica muy beckettiana que persigue al dramaturgo cuando éste a su vez persigue a sus hembras y delata sus íconos en cualquier intento de 
escapar al dolor del cuerpo y al corazón negro, humanamente envilecido en todas sus encarnaciones. Hay una ternura dramatúrgica hacia el animal herido, animal de fondo. El arte secreto de la actriz es su incapacidad para ser la otra. De nuevo, tras casi un centenar de piezas en su haber, el taller de De la Parra y su fascinación con los teatros de la mente que son bacantes del impulso físico. El deseo de ellas y para ellas, celebración de los teatros del cuerpo que deriva en una lúdica incomprensión de sí mismo. Duelo emocional que no tiene su origen en una incapacidad de aproximación a la realidad sino en una profunda reflexión sobre la actuación teatral y social y la presencia efectiva de no-actores o actores desorbitados en escena. El teatro intentará renovarse mediante la introducción aparentemente inocente de lo real, fracasando y renunciando a construir lo real, desbordados por la emoción dramática de la realidad.

Una mujer en la ventana. Pero no es el apacible cuadro de Dalí. Adelante, dice, metteur en scéne.

Madrid, España 
